\title{
Detection of Bovine Papillomavirus in Cutaneous Lesions by Polymerase Chain Reaction (PCR) in Cattle
}

\author{
T. Lurthu Reetha*, R. Manickam and B. Puvarajan \\ Department of Veterinary Microbiology, Veterinary College and Research Institute, \\ Orathanadu, Thanjavur, India \\ *Corresponding author
}

\section{A B S T R A C T}

Keywords

Livestock, Bovine papilloma,

Virology,

Polymerase chain reaction

Article Info

Accepted:

12 March 2020

Available Online:

10 April 2020
Bovine papillomavirus (BPV) causes benign tumours in the mucosal and cutaneous epithelium and is characterized by the presence of warts. The present study includes the molecular identification of BPV strains in samples of warts using degenerate polymerase chain reaction (PCR) primers FAP59/64. Wart samples were collected from the cattle having typical lesions on various parts of the body. The present study showed that PCR amplification with the primers FAP59/64, which partially amplify the L1 gene and showed the 470bp amplicon size, indicating BPV. The results in this study are important for the development of prophylactic and therapeutic measures that contribute to reducing the economic losses associated with BPV.

\section{Introduction}

Bovine papillomaviruses (BPV) are causative agents of benign and malignant tumors in cattle, such as cutaneous papillomas, fibropapillomas, and urinary bladder and esophageal cancers, causing significant economic losses (Stocco dos Santos et al., 1998; Vázquez et al., 2012; Carvalho et al., 2013). There are 14 types of BPV, which have been classified into 3 separate genera: Delta, Epsilon, and Xi. Each can cause typespecific lesions (Borzacchiello et al., 2008).
BPV-1, BPV-2, and BPV-13, for example, are classified in the Deltapapilloma virus genus and induce fibropapilloma (Lunardi et al., 2013). They are also capable of infecting diverse host species, causing equine sarcoid (Nasir and Reid, 1999).

Lesions of the teats and udders in cattle are commonly related to BPV-1 (Jarrett et al., 1984). Fibropapilloma in the penis is also associated with BPV-1 and leads to necrosis and loss of reproductive function (Gardiner $e t$ al., 2008). 
In cutaneous fibropapilloma, BPV-2 is a causative agent of malignant bladder tumors (Jarrett et al., 1984). Most of these types of viruses have also been detected in the peripheral blood and reproductive tissue samples of cattle, resulting in vertical transmission (Diniz et al., 2009). BPV Xipapillomavirus types (Carvalho et al., 2013) are considered selective epitheliotropic viruses, inducing the formation of true papillomas (Hatama et al., 2011). In contrast, the BPV Epsilonpapillomavirus types can induce fibropapillomas and true papillomas (Tomita et al., 2007). BPV-7 is grouped separately (Ogawa et al., 2007).

While hundreds of human papillomavirus (HPV) types have been identified, only six BPV types had been characterized until the early 1980s (Jarret et al., 1984, Bernard 2005). However, recent studies employing PCR with generic primers FAP59/FAP64 in combination with cloning and sequencing, have described 15 putative new BPV types (Forslund et al., 1999, Antonsson and Hansson 2002, Ogawa et al., 2004).

After characterization of their complete genome sequences, four of these Japanese isolates were recently recognized as new viral types (BPV- 7, -8, -9, and -10) (Ogawa et al., 2007, Tomita et al., 2007, Hatama et al., 2008). In addition, four putative new BPV types have been identified in cutaneous lesions from cattle herds in Parana state, Brazil (Claus et al., 2008).

In cattle, bovine papillomavirus (BPV) induces exophytic lesions (papillomas, warts) and flat lesions (flat warts, cervical intraepithelial neoplasia) in cutaneous and mucosal epithelia (de Villiers et al., 2004; Dyne et al., 2018).

BPV-induced benign lesions regress spontaneously; however, they may develop into cancer, especially in the presence of cofactors such as environmental carcinogens (Corteggio et al., 2013). BPV diagnosis usually includes a clinical examination, histopathology, and immunohistochemistry (Betiol et al., 2012).

Polymerase chain reaction (PCR) has been used as a sensitive method for the identification and genotyping of BPV (Leto et al., 2011). Specific primers have also been successfully employed mainly for BPV identification in blood (Araldi et al., 2014). BPV contains a double-stranded, circular, 8kb DNA genome divided into the following 3 regions: an early region, a long control region, and a late region, which encodes several important proteins (Zheng and Baker, 2006).

Although infections caused by BPV in cattle do not cause much damage, they produce great economic losses due to their impact on aesthetics and the quality of cattle in livestock shows and hinder the commercialization of products derived from animals infected with BPV, such as leather for the production of footwear and other clothing (Catroxo et al., 2013; Araldi et al., 2014). However, superinfections in lesions and milking difficulties when papillomas appear on the udders can cause considerable health and management complications, and finally, some genotypes are associated with the development of carcinogenic lesions (Campo et al., 1992; Borzacchiello et al., 2003).

The molecular characterization described in this report will establish a guide for subsequent studies with a greater number of samples. The results of this research are important because they contribute to the development of prophylactic and therapeutic measures that minimize economic losses associated with the presence of papillomavirus in cattle. 


\section{Materials and Methods}

\section{Animal and sample collection}

Samples are collected from animals showing cutaneous papillomatous lesion that were brought to clinics by the owners. The collected tissue samples had varying diameters $(5-10 \mathrm{~cm})$ and came from different parts of the body (e.g., udder, teat, abdomen, and back). All the samples were immediately stored at $-21^{\circ} \mathrm{C}$ until processing in the laboratory. The clinical specimens were taken by hand (wearing gloves, changed for each sample), packed individually, and maintained at $4^{\circ} \mathrm{C}$ until the DNA extraction procedure was completed.

Fragments from each skin wart were triturated in phosphate-buffered saline solution (PBS $\mathrm{pH} 7.2)$, and the suspensions (10-20\%, w/v) were centrifuged for $15 \mathrm{~min}$ at $3000 \mathrm{x} g$ at $4^{\circ} \mathrm{C}$. Aliquots $(250 \mu \mathrm{L})$ of the supernatant were treated with lysis buffer [10 mM Tris; 1 mM EDTA; 0.5\%Nonidet P40; 1\% SDS; and $0.2 \mathrm{mg} / \mathrm{mL}$ proteinase $\mathrm{K}$ (Invitrogen, Life Technologies, USA)]. After homogenization, the samples were incubated at $56^{\circ} \mathrm{C}$ for 30 min. Total DNA was extracted from bacterial isolates by using commercially genomic DNA mini kit (Qiagen - Germany) following the mini spin protocol according to the manufacturer's instructions.

\section{PCR amplification and electrophoresis}

PCR was performed in the region of the FAP gene that encodes the viral protein L1 (Carvalho et al., 2013). The reaction was performed using a final volume of $20 \mu \mathrm{l}$, which included 1 to $5 \mathrm{ng}$ of DNA, $0.5 \mu \mathrm{M}$ each primer, FAP59 (5'-TAAC WGTIGGICAYCCWTATT-3') and FAP 64 (5'- CCWATATCWVHC ATITC ICCATC3'), $0.2 \mathrm{mM}$ each DNTP, 1X PCR buffer, 1.5 $\mathrm{mM} \mathrm{MgCl} 2$ and $1 \mathrm{U}$ of Taq DNA polymerase.
Amplification consisted of an initial denaturation of $5 \mathrm{~min}$ at $95^{\circ} \mathrm{C}$, followed by 35 cycles of 60 econds at $95^{\circ} \mathrm{C}, 60$ seconds at $52^{\circ} \mathrm{C}$ and 60 seconds at $72^{\circ} \mathrm{C}$, with a final extension of $5 \mathrm{~min}$ at $72^{\circ} \mathrm{C}$. The amplification products were analysed by electrophoresis in a $1.2 \%$ agarose gel in TBE buffer $\mathrm{pH} 8.4$ (89mM Tris; $89 \mathrm{mM}$ boric acid; $2 \mathrm{mM}$ EDTA) at constant voltage $(50 \mathrm{~V})$ for approximately $45 \mathrm{~min}$, stained with ethidium bromide $(0.5 \mu \mathrm{g} / \mathrm{ml})$, and visualized under UV light. The presence of a band of 470 base pairs (bp) indicated that the virus was present.

\section{Results and Discussion}

The presence of the $470 \mathrm{bp}$ fragment established as indicative of infection caused by the virus is shown in Figure 1. This fragment size is similar to that reported by Carvalho et al., (2013), who studied the virus in a herd of Holstein cattle affected by chronic cutaneous papillomatosis. However, Araldi et al., (2014), using the same set of primers, reported a 478 bp fragment in cutaneous papillomas in samples of Angus Red cattle in Sao Paulo, Brazil.

Similarly, Claus et al., (2009), in a study conducted in beef cattle in Paraná, Brazil, reported a 480 bp amplicon size using the same sets of primers as in the present study (FAP59/FAP64). However, all amplicons, after subsequent sequencing, were confirmed as positive for BPV. The variability in the size of base pairs was previously described by Carvalho et al., (2013), who reported sizes ranging between 469 and $484 \mathrm{bp}$ in different viral strains. This fact highlights the importance of using sequencing, in addition to using specific segments of the viral fragment that we wish to amplify because it allows comparative studies of the different genotypes found in an outbreak where the presumptive diagnosis is BPV. 


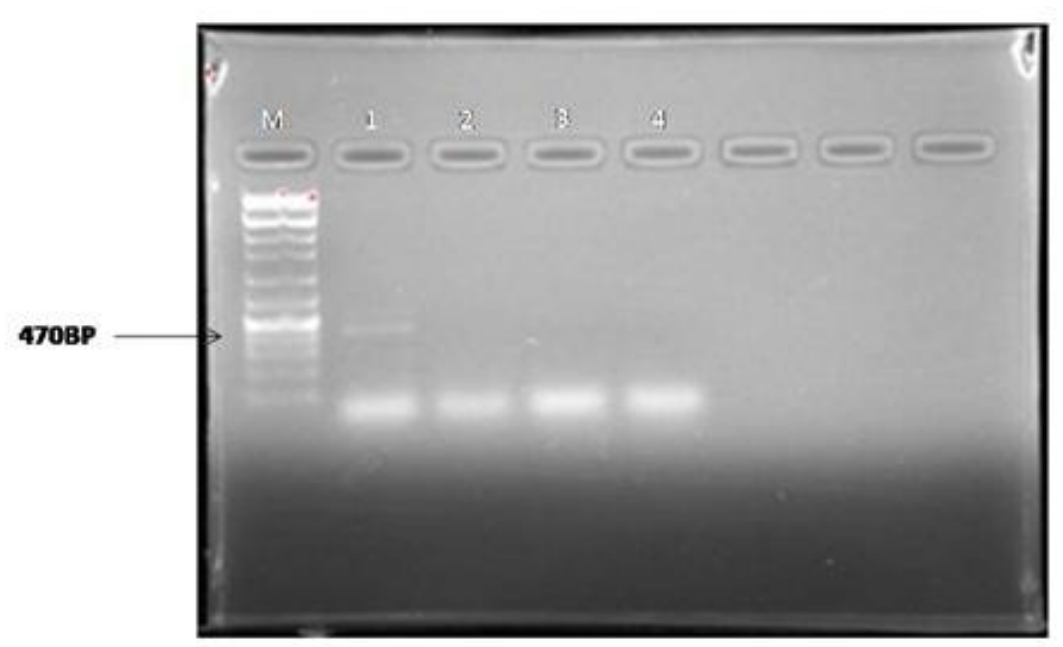

Figure.1 PCR products (470 bp) for the L1 gene of bovine papillomavirus in wart samples using primers FAP59/64. Lane 1 represent positive samples; Lane 2, 3 and 4 represents negative sample and Lane M represents molecular weight markers from 100 to 1000 base pairs

\section{Acknowledgement}

We are thankful to all the Staff, Department of Veterinary Clinical Complex, Veterinary College and Research Institute, Orathanadu, who alerted us of and assisted us in the collection of cutaneous wart samples.

\section{References}

Antonsson A. and Hansson B.G. 2002. Healthy skin of many species harbours papillomaviruses which are closely related to their human counterparts. J. Virol. 76(24): 12537-12542.

Araldi RP, Carvalho RF, Melo TC, Diniz NSP, Ana TAS (2014). Bovine papillomavirus in beef cattle: first description of BPV-12 and putative type BAPV8 in Brazil. Genetics and Molecular Research 13(3): 5644-5653.

Bernard H.U. 2005. The clinical importance of the nomenclature, evolution and taxonomy of human papillomaviruses. J. Clin. Virol. 32:1-6.

Betiol JC, Kignel S, Tristão W, Arruda AC, et $a l$, HPV 18 prevalence in oral mucosa diag-nosed with verrucous leukoplakia: cytological and molecular analysis. J
Clin Pathol 2012; 65: 769-770.

Borzacchiello G, Iovane G, Marcante ML, Poggiali F, Franco R, Roperto S, Venuti A (2003). Presence of bovine papillomavirus type 2 DNA and expression of the viral oncoprotein E5 in naturally occurring urinary bladder tumours in cows. Journal of General Virology 84(Pt 11): 2921-2926.

Borzacchiello G, Roperto F: Bovine papillomaviruses, papillomas and cancer in cattle. Vet Res 2008; 39: 45.

Campo MS, Jarrett WF, Barron R, O'Neil BW, Smith KT (1992). Association of Bovine Papillomavirus Type 2 and Bracken Fern with Bladder Cancer in Cattle. Cancer Research 52(24): 68986904.

Carvalho RF, Sakata ST, Giovanni DNS, Mori E, Brandao PE, Richtzenhain LJ, Pozzi CR, Arcaro JRP, Miranda MS, Mazzuchelli-de-Souza, Melo TC, Comenale G, Assaf SLMR, Becak W, Stocco RC (2013). Bovine Papillomavirus in Brazil: Detection of Coinfection of Unusual Types by a PCR-RFLP Method. BioMed Research International 2013: 270898. https://www.hindawi.com/journals/bmri 
/2013/270898/

Catroxo MHB, Martins AM, Petrella S, Souza F, Nastari BDB (2013). Ultrastructural Study of Bovine Papillomavirus During Outbreaks in Brazil. International Journal of Morphology 31(2):777-784.

Claus M.P., Lunardi M., Alfieri A.F., Ferracin L.M., Fungaro M.H.P. and Alfieri A.A. 2008. Identification of unreported putative new bovine papillomavirus types in Brazilian cattle herds. Vet. Microbiol. 132:396-401.

Claus P, Lunardi M, Alfieri AF, Sartori D, Helena M, Fungaro P, A Alfieri (2009). Identification of the recently described new type of bovine papillomavirus (BPV-8) in a Brazilian beef cattle herd. Pesquisa Veterinária Brasileira 29(1):25-28.

Corteggio A, Altamura G, Roperto F, Borzacchiello G: Bovine papillomavirus E5 and E7 oncoproteins in naturally occurring tumors: are two better than one? Infect Agent Cancer 2013; 8: 1.

De Villiers EM, Fauquet C, Broker TR, Bernard HU, Zur Hausen H (2004). Classification of papillomaviruses. Virology 324(1):17-27.

Diniz N, Melo TC, Santos JF, Mori E, et al., Simultaneous presence of bovine papillomavirus in blood and in shortterm lymphocyte cultures from dairy cattle in Pernambuco, Brazil. Genet Mol Res 2009; 8: 1474- 1480.

Dyne EA, Henley SJ, Saraiya M, Thomas CC, Markowitz LE, Benard VB (2018). Trends in human papillomavirusassociated cancers - United States, 1999-2015. Morbidity and Mortality Weekly Report 67(33):918-924.

Forslund O., Antonsson A., Nordin P. and Hansson B.G. 1999. A broad range of human papillomavirus types detected with a general PCR method suitable for analysis of cutaneous tumours and normal skin. J. Gen. Virol. 80:2437-
2443.

Gardiner DW, Teifke JP, Podell BK, Kamstock DA: Fibropapilloma of the glans penis in a horse. J Vet Diagn Invest 2008; 20: 816-819.

Hatama S, Ishihara R, Ueda Y, Kanno T, et al., Detection of a novel bovine papillomavirus type 11 (BPV-11) using Xipapillomavirus consensus polymerase chain reaction primers. Arch Virol 2011; 156: 1281-1285.

Hatama S., Nobumoto K. and Kanno T. 2008. Genomic and phylogenetic analysis of two novel bovine papillomaviruses, BPV-9 and BPV-10. J.Gen. Virol. 89:158-163.

Jarrett WF, Campo MS, O'Neil BW, Laird HM, et al., A novel bovine papillomavirus (BPV-6) causing true epithelial papillomas of the mammary gland skin: a member of a proposed new BPV subgroup. Virology 1984; 136: 255-264.

Leto M, Santos Júnior GF, Porro AM, Tomimori J: Human papillomavirus infection: etiopathogenesis, molecular biology and clinical manifestations. An Bras Dermatol 2011; 86: 306-317.

Lunardi M, Alfieri AA, Otonel RA, de Alcantara $\mathrm{BK}$, et al., Genetic characterization of a novel bovine papillomavirus member of the Deltapapillomavirus genus. Vet Microbiol 2013b; 162: 207213.

Nasir L, Reid SW: Bovine papillomaviral gene expression in equine sarcoid tumours. Virus Res 1999; 61: 171-175.

Ogawa T., Tomita Y., Okada M. and Shirasawa H. 2007. Complete genome and phylogenetic position of bovine papillomavirus type 7. J. Gen.Virol. 88:1934-1938.

Ogawa T., Tomita Y., Okada M., Shinozaki K., Kubonoya H., Kaiho I. and Shirasawa H. 2004. Broad-spectrum detection of papillomaviruses in bovine 
teat papillomas and health teat skin. J. Gen. Virol. 85:2191-2197.

Stocco dos Santos RC, Lindsey CJ, Ferraz OP, Pinto JR, et al., Bovine papillomavirus transmission and chromosomal aberrations: an experimental model. J Gen Virol 1998; 79: 2127-2135.

Tomita Y., Literák I., Ogawa T., Jin Z. and Shirasawa H. 2007. Complete genomes and phylogenetic positions of bovine papillomavirus type 8 and a variant type from a European bison. Virus Genes
35:243-249.

Vázquez R, Escudero $\mathrm{C}$, Doménech A, Gómez-Lucia E, Benítez L (2012). Review. Papilomatosis Bovina: Epidemiología y Diversidad de Papilomavirus Bovinos (BPV). Revista Complutense de Ciencias Veterinarias 6(2):38-57.

Zheng ZM, Baker CC: Papillomavirus genome structure, expression, and posttranscriptional regulation. Front Biosci 2006; 11: 2286-2302.

\section{How to cite this article:}

Lurthu Reetha, T., R. Manickam and Puvarajan, B. 2020. Detection of Bovine Papillomavirus in Cutaneous Lesions by Polymerase Chain Reaction (PCR) in Cattle. Int.J.Curr.Microbiol.App.Sci. 9(04): 1611-1616. doi: https://doi.org/10.20546/ijcmas.2020.904.188 